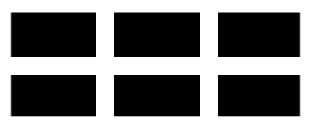

ThE WILLIAM DAVIDSON INSTITUTE AT THE UNIVERSITY OF MICHIGAN BUSINESS SCHOOL

\title{
Reintroducing Intergenerational Equilibrium: Key Concepts behind the New Polish Pension System
}

\author{
By: Marek Góra
}

William Davidson Institute Working Paper Number 574

June 2003 


\title{
$\underline{\text { Reintroducing Intergenerational Equilibrium: Key Concepts }}$ \\ behind the New Polish Pension System
}

\author{
Marek Góra ${ }^{1,2}$
}

\begin{abstract}
$\underline{\text { Abstract }}$
Poland adopted a new pension system in 1999. This new pension system allows Poland to reduce pension expenditure (as a percent of GDP), instead of increasing it as is projected for the majority of other OECD countries. This paper presents the conceptual background of the new system design. The new system's long-term objective is to ensure intergenerational equilibrium irrespective of the demographic situation. This requires stabilisation of the share of GDP allocated to the entire retired generation. Traditional pension systems aim, instead, at stabilisation of the share of GDP per retiree. The change in demographic structure observed over the past for a couple of decades and this historic attempt to stabilise the share of GDP per retiree led to severe fiscal problems and negative externalities for growth, as observed in numerous countries. Many countries have tried to reform their pension systems in different ways to try to resolve the issue of these ever-increasing costs. Although the Polish reform uses a number of techniques applied elsewhere, its design differs from the typical approaches - and the lessons and results are promising for all OECD countries. This paper presents the theoretical and practical application of this alternative approach and as such, the key features of the new Polish pension system design.
\end{abstract}

Keywords: pensions, equilibrium, GDP, pension debt servicing, income allocation, generations.

JEL codes: D50, H55, H63.

\footnotetext{
${ }^{1}$ Marek Góra was a pension reform team leader and the author of the new Polish pension system design (together with Michal Rutkowski). He is a professor at Warsaw School of Economics (SGH).

${ }^{2}$ The author thanks Jim Kernan of PricewaterhouseCoopers for his comments and help in editing this paper.
} 


\section{Introduction}

Demographic transition together with myopic policies has caused severe problems in the area of pensions in many countries around the world. Elements of traditional pension systems' design include a weak link of benefits to contributions and the lack of control over costs of the system. Inclusion of these elements in the pension system design led to the explosion of costs, caused negative externalities for growth and contributed to persistently high unemployment. As such, the quest for pension reform is now on the top of policy agendas around the world, and especially in Europe.

However, very few countries have been able to introduce fundamental reforms in the area of pensions to this time. In this case, the definition of reform is crucial. For the purposes of this paper, "reform" means changing the system in order to remove structural inefficiencies - and not just playing at the margins with contribution rates and retirement ages to adjust the system's parameters for short-term fiscal and political reasons. $^{3}$

Traditional pension systems have proven to be inefficient in providing societies with social security. At the same time attempts to cure these systems are hampered by a lack of consensus on what could replace the traditional system. Discussions on this issue involve confusion stemming from the ideological context of the discussion participants, as well as from overuse of such concepts as "pay-as-you-go" versus "funding", or "public" versus "private", while at the same time ignoring a number of important economic issues.

Furthermore, economists have traditionally ignored pensions. Designing and running pension systems was left to non-economists, who were not extensively concerned with how to finance pensions in the long-term or with how to counteract these pension systems' negative externalities. The new Polish pension system belongs to very small number of successful attempts to apply modern thinking in the area of pensions ${ }^{4}$. This does not mean - as some may assume - giving up social security goals. Rather, the key idea was to give up the inefficient methods of delivering social security in order to save its goals and principles.

\footnotetext{
${ }^{3}$ This distinction plays important role in thinking on pension reforms. For more discussion see Góra and Rutkowski (1998), also Holzmann, Orenstein and Rutkowski (2003).

${ }^{4}$ Sweden and UK are among other examples of successful pension reforms.
} 
This paper consists of two parts. The first focuses on a discussion of general issues that need to be addressed when designing a pension system. These issues are presented in a way that goes beyond the traditional way of thinking on pensions.

In regards to this second part of the paper, it is important to point out that most countries in the current EU member states and candidate countries have pension systems that are essentially the same at the basic policy level. As such, the solutions in one member state or candidate country can be expected to be the same.

Like European states such as France, Germany, Italy, the Czech Republic, Hungary and other European states, Poland and Sweden over the past decades and until the late 1990's developed inefficient, costly pension systems. As such, in part two of the paper we shall examine how Poland has now successfully implemented the approach presented in the first part of the paper, and created a fundamentally strong and neutral pension system.

\section{Selected general issues}

Pension system design has to take into account a number of issues. Their full presentation and discussion goes beyond the scope of this paper. ${ }^{5}$ This paper presents only a list of the issues for consideration and the most important observations.

\section{The pension system: externalities versus neutrality}

The description of a pension system depends strongly on both the aggregated and individual viewpoint.

From the aggregated perspective, the pension system is a way of dividing current GDP between a part kept by the working generation $\left(\mathrm{GDP}^{\mathrm{W}}\right)$ and a part allocated to the retired generation $\left(\mathrm{GDP}^{\mathrm{R}}\right)$.

From the individual perspective, the pension system is a way of income allocation over a person's life cycle.

\footnotetext{
${ }^{5}$ For broader explanation and discussion of theoretical background of author's views on the pension system see Góra (2003a).
} 
The above holds irrespective to the technical method applied or the ideological viewpoint. The pension system - as defined above - is not necessarily pay-as-you-go or funded. Such features stem from technical elements additionally applied on the top of the pension system, rather than from the system itself. If the pension system design assumes anonymous participation and a substantial scale of redistribution then we usually call this system pay-as-you-go. If the pension system design uses financial markets, then we usually call it funded.

However, these two typically used concepts do not exhaust all possible combinations of anonymous versus individualised participation and financial versus non-financial pension system design techniques used. The dualistic pay-as-you-go versus funded approach leaves aside the combination of individual participation in a system that does not use financial markets. This approach also neglects the fact that using financial markets means investment (pension portfolio consists of private equities) or deferring taxes (pension portfolio consists of government bonds), which is obviously not the same.

Adding redistribution or financial markets to the pension system generates externalities. These externalities can be positive and negative. Redistribution within the pension system can generate positive externalities if the system is inexpensive, namely the part of GDP allocated to the retired generation is not large. If the redistribution is large, then it generates negative externalities, such as contributing to persistently high unemployment and weak growth. Using financial markets causes positive externalities for growth if the pension system spends contribution money on investment. If the contributions are spent on government debt they may lead to negative externalities similar to those of large redistributive system, namely more tax distortions. This can happen if the rate of return on government debt is persistently above the rate of GDP growth.

There exists yet another option, namely to bring the pension system as close to economic neutrality as possible. This option requires, among other things, combining individual participation in the system with dividing GDP between generations based on real economy developments, such as has been done in Poland and Sweden. 
Demographic structure: consequences of the change

Irrespective of the pension system design technique used, the pension system exchanges a right of the retired generation for a part of the product of the working generation. The exchange can be organised in various ways and also the rights can be expressed in various ways. In particular, the rights can be either traded in the financial markets, or defined in relation to some economic variables, or just based on political promise. In all of these cases there is a kind of market for pension rights. The working generation finances contributions in order to purchase the rights; the retired generation sells the rights in order to get a part of the product of the working generation. The various types of pension systems create an institutional framework for this market.

Given the contribution rate, the demand side of the market is determined by the number of workers and their productivity. The number of retirees determines the demand side. However, if - as it is the case in traditional systems - pensions are administratively defined in terms of wages (replacement rate promised) then the pension system depends solely on the demographic structure. Even strong productivity growth cannot help in balancing the system's revenue and expenditure.

The general change of the demographic structure we see around the world has caused the pyramid scheme used for financing pension expenditure to no longer generate sufficient revenues. In consequence, previous minor inefficiencies have become devastating. Ageing turned the previous "pyramid-shape" demographic structure into a new "hut-shape" one, as illustrated in Figure $1 .^{6}$

\footnotetext{
${ }^{6}$ Compare literature on the Second Demographic Transition. See van de Kaa (1996).
} 
Figure 1. Demographic structure and the pension system

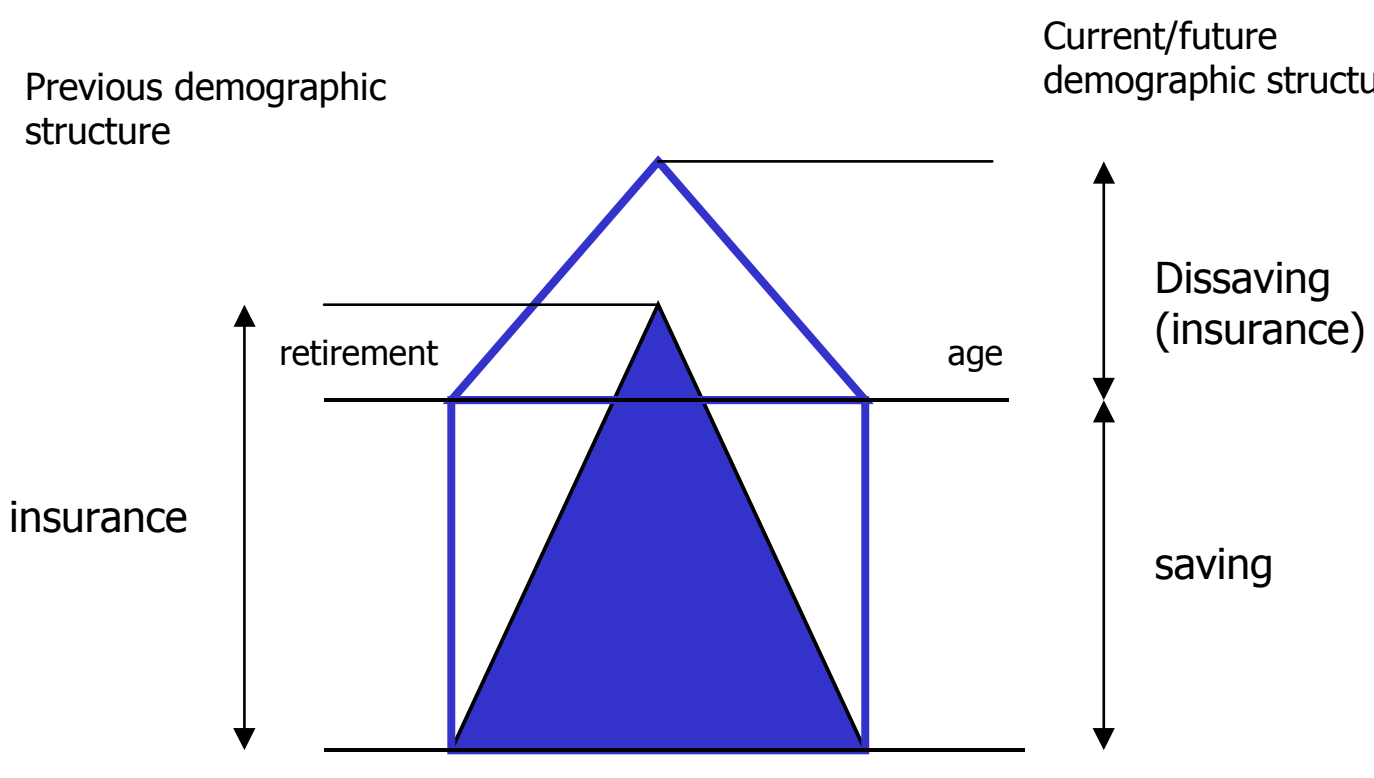

The pension system strongly depends on the demographic structure of the population. There is no escape from this dependency irrespective of pension system technique used. Using financial markets do not make pension systems immune from this dependency. Financial markets do help, however, in adjusting the system to the current demographic situation by introducing an easy to understand and acceptable link between benefits and contributions paid.

The general change of the demographic structure around the world has caused severe fiscal problems for many countries. This change can be seen also from the viewpoint of being able to achieve the traditional social goals of the pension system. In this regard, two important observations are worth mentioning:

In the past, the minority - nowadays the vast majority - of those who pay contributions to the system as workers, afterwards receive benefits as retirees. This means that in the active phase of the individual's life, participation in the pension system is very similar to long term saving. As the goal is to provide for each individual, using the individual as the main accounting unit becomes a superior way to organize the pension system. 
In the past, the pension system channelled $\mathrm{GDP}^{\mathrm{R}}$ to the very old people who were unable to earn a living and finance consumption on their own. Nowadays people who retire are still able to work and earn, and they - on average have many years of life left to live.

As such, the discussion above shows that the objective of the pension system has changed for the old-age part of the pension system (OA). However, the non-old-age parts of social security systems (NOA), such as disability, remain risk related, irrespective to ageing. This leads to the conclusion that the various parts of the social security system should be segmented, such that revenues (contributions) and expenses (benefits) can be tied to their purpose exclusively over time, and each segment insulated from each other. ${ }^{7}$ In this way, policy makers would be able to look at each segment of the social security system, knowing that its revenues and expenses have been insulated from the risks of other parts of the system and are an accurate reflection of the current state of that segment and together of the system as a whole. The social security system, would then be made of an OA segment (pensions) and various NOA segments (disability, maternity, worker's compensation, and so forth). This operational and accounting reform is one of the most important non-fiscal reasons for a deep pension reform and would provide policy makers with a powerful tool to understand how well their social security system can and will meet its goals.

\section{$\underline{\text { Macroeconomic consequences of demographic change }}$}

Traditional pension systems try to keep constant the part of GDP per retiree $\left(G D P / L^{R}=\right.$ const $) .{ }^{8}$ This is why the demographic change Europe faces strongly affects its growth. This problem applies, at least partially, to other continents as well. Fewer people produce GDP; more people participate in dividing GDP who did not participate in producing it. At the aggregated level, ageing leads to an increase of the $G D P^{R} / G D P$ ratio. We can call this ratio the economic dependency ratio (EDR).

\footnotetext{
${ }^{7}$ This is much like would be done in the financial statements/accounting treatment of a company, when one is trying to analyse which are the profit and loss making operations.

${ }^{8}$ This arrangement is usually called defined benefit. In my opinion this is only partially correct. Defined benefit, as well as defined contribution is a term appropriate for voluntary (partial) programmes rather than for universal systems.
} 
Consequently, a smaller part of GDP is spent on rewarding employment of production factors and productivity growth, which slows down growth. At the individual level, ageing leads to turning insurance-based participation in the pension system into social tax based participation, which adds to tax distortions slowing down growth. Both effects became strong in last decades of the twentieth century and - according to projections - will be even stronger in the decades to come. Table 5 provides projections for OECD countries. The general macroeconomic consequences are presented in Figure 2.

In Figure 2, line A represents projected values of the EDR rate growing due to the demographic change as well as to political decisions on the systems' generosity (replacement rate, retirement age). The larger EDR rate the weaker, ceteris paribus, growth. ${ }^{9}$ We can already observe this in many economies (see Table 5). Line B represents stabilisation of the EDR rate on a current level. Line $\mathrm{C}$ represents reduction of the EDR rate to an optimal level. The analysis of how the optimal EDR level could be defined would be the subject of another paper.

\footnotetext{
${ }^{9}$ If we assumed the extreme situation, namely EDR $=1$, then GDP would be close to zero.
} 
Figure 2. Developments of the share of GDP allocated to the retired generation

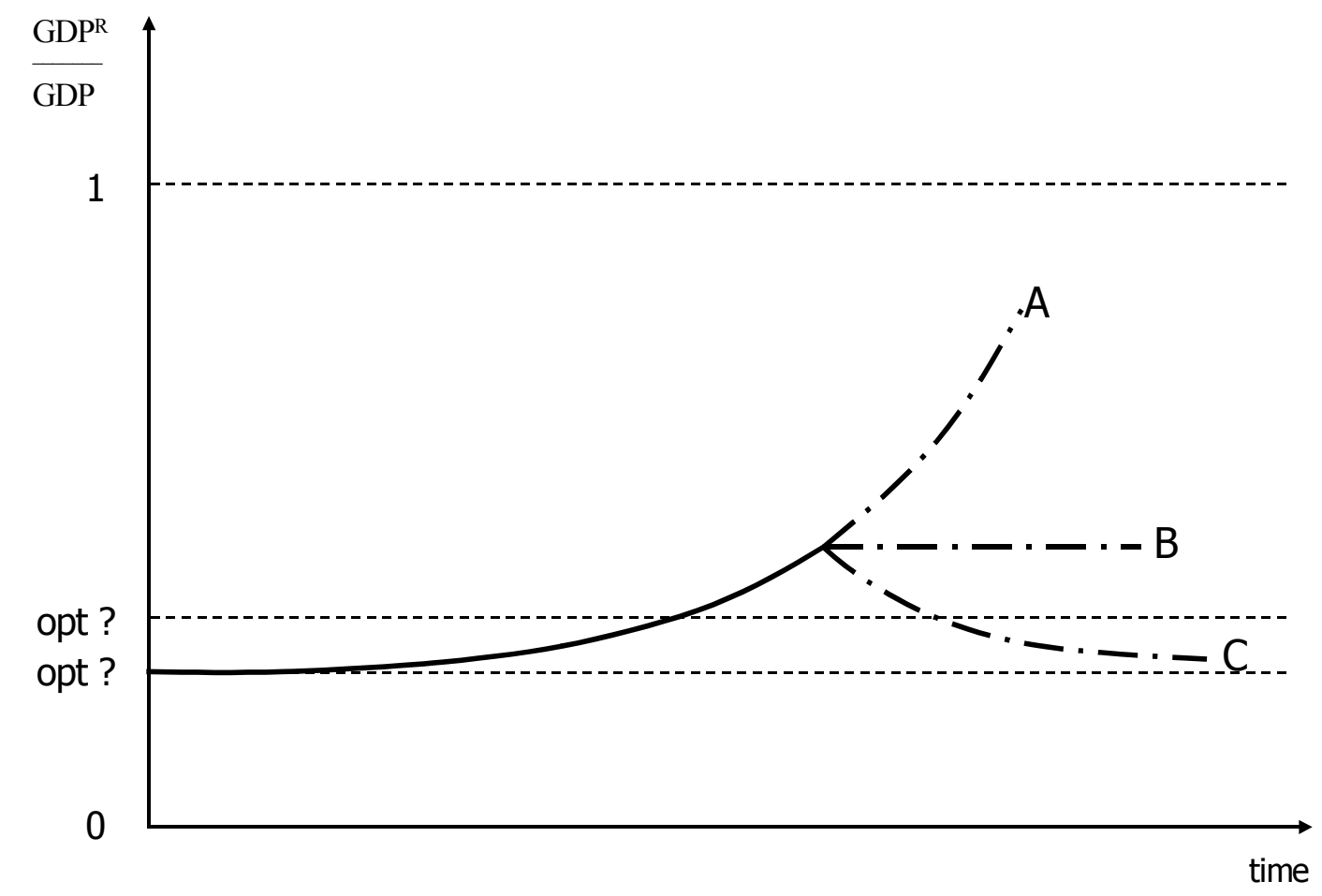

Each generation is first a working generation that buys pension rights, and afterwards a retired generation selling accumulated rights. If each generation's welfare is equally important then it is the only Arrow-Debreu equilibrium (Nash equilibrium if we define generations as players) that is Pareto optimal. It requires each generation receives from the pension system present value of benefits equal to the present value of contributions paid. ${ }^{10}$ If one generation received more than it paid in, then another generation would receive less than it paid in. In such situation, preferences are inconsistent in the period of participation in the pension system, hence, there is no equilibrium at all, or the system prefers one generation over others, hence it enforces allocation not being Nash equilibrium.

In order to avoid causing persistently weak growth, the pension system should be designed in a way that stabilises the EDR ratio instead of stabilising GDP per retiree. However, the current contribution rate is not necessarily optimal. Pension system design should also take into account individual preferences on the scale of income

\footnotetext{
${ }^{10}$ Discounting factor is the GDP growth rate.
} 
allocation. Since returns in universal (mandatory) pension systems are lower or are perceived as lower that would be possible in voluntary savings, the mandatory contributions should be kept as low as possible just to avoid myopia and free riding. Promised generous pensions are not necessarily good. The same concerns all leakages from the pension system such as inheriting account values or annuities. If, for instance, pension rights (including account values) can be inherited, then higher contributions are needed in order to generate the same level of pensions.

\section{$\underline{\text { Coverage: Universal versus partial }}$}

Universal pension systems are needed to avoid the costs of myopia and free riding. At the same time, due to mandatory participation - which is the only way to ensure universal coverage - universal pension systems generate negative externalities. The larger a pension system is, the stronger the negative externalities are. Generous universal schemes are not necessary good ones, as a promised high level of income after retirement imposes a high burden before retirement.

Universal coverage strongly differs from partial coverage based on voluntary decisions and responsibility. This issue is extremely important, because in many cases reforming pension systems means either creating incentives for participation in voluntary programmes or just making mandatory previously voluntary programmes. However, designing a good universal pension system needs more.

The following points are a number of examples that illustrate the difference between universal and partial coverage.

$>$ Inheriting account values or other forms of pension rights is natural in partial programmes. In universal systems inheriting pension rights just increases mandatory costs imposed on workers.

$>$ Offering participants a wide choice of decisions is requisite in partial programmes. In universal systems, a wide degree of decisions may lead to creating the possibility to make mistakes or obtain additional benefits at the expense of the rest of population.

$>$ Buying government debt is natural in partial programmes and makes sense especially when interest on this debt is high. This means redistribution from those 
who have not bought this debt to those who have. In universal systems this means redistribution from everybody to everybody and may lead to a need to increase taxes.

\section{Generosity: Adjusting pensions in advance}

Stabilisation of the EDR ratio, given projected demographic change, leads to a reduction in the replacement rate. This can be a social argument against such an approach. Actually this argument is widely used in public discussions. However, the argument is based on the assumption that governments are able to keep increasing the EDR ratio. The assumption is hardly acceptable given current levels of the tax wedge and resistance against substantial increases in the retirement age in the OECD area and also in many countries outside this area.

In fact, running a traditional system that promises constant a $G D P / L^{R}$ ratio is similar to running a Ponzi scheme. ${ }^{11}$ One can argue that counter to the Ponzi scheme the universal pension system can be subsidised, which is usually called a "state guarantee". However, this "state guarantee" brings us back to the problem of whether the tax wedge can be further increased. In the long run - which is the appropriate horizon for thinking on pensions - the $G D P / L^{R}=$ const. regime could be maintained only if dependency ratio fluctuated over a long run average. This regime cannot be maintained if, ceteris paribus, the opposite holds. Irrespective to the particular design of the pension system, workers who pay contributions now will not receive the same individual share of GDP as the current generation of retirees - unless they and their children pay higher contributions or taxes, which would mean increasing the EDR rate. Summarising, the long-term sustainable level of the replacement rate $(z)$ is determined by the dependency ratio (d) and the choice of the contribution rate $\left(\mathrm{c}^{\mathrm{W}}\right)$ financed by the working generation. ${ }^{12}$

$$
z=c^{W} \frac{1}{d}
$$

\footnotetext{
${ }^{11}$ This was always known, but was however, neglected.

${ }^{12}$ The true contribution rate includes subsidies financed out of general taxes.
} 
Given the share of wages in GDP, the decision on the contribution rate determines the share of GDP allocated to the retired generation (EDR).

However, the real value of future pensions depends not only on the replacement rate but also on value of GDP itself. Thus, a pension system based on a stable EDR ratio will contribute to stronger GDP growth and will provide higher pensions than a system in which a growing share of GDP ${ }^{\mathrm{R}}$ would slow down GDP growth.

In the short run Equation (1) can be violated. Namely the replacement rate can be kept above the sustainable level, through further increasing pension system debt that will never be paid back. This is a temptation for politicians all over the world (and one to which they often succumb). However, in the long run, given obvious limits for increasing the contribution rate, future reduction of the replacement ratio is inevitable with or without a reform. So there are only two options:

$>$ either a reform, which means cutting down pension expectations (expressed as the replacement rate) ex ante;

$>$ or no reform, which will lead to cutting down pensions ex post.

Choosing the latter would just be cheating the current generation of workers. It should be made clear that a small working population will never be able to provide a large retired population with relative per capita income at the level comparable to what was possible in the case of large working population sharing its product with a small retired population. ${ }^{13}$

\section{Different types of individual accounts}

Individual participation in the pension system needs individual accounts in order to register pension obligations owned by participants. The accounts can be of three different types, namely non-financial accounts (NDC), financial accounts based on government debt $\left(\mathrm{FDC}_{\mathrm{GD}}\right)$, and financial accounts based on private equities $\left(\mathrm{FDC}_{\mathrm{PE}}\right)$. These accounts differ in two main ways. First, whose liability is the obligation created by contributions paid into the system; second, how is the rate of return earned

\footnotetext{
${ }^{13}$ This can be overcome only if the consecutive working generations accept a downward trend in rewarding of labour and capital.
} 
financed by these contributions. There are a number of other differences of which the most important ones are presented in Table $1 .^{14}$

Table 1. Three types of individual accounts

\begin{tabular}{|l|l|l|l|l|l||}
\hline $\begin{array}{l}\text { Type of } \\
\text { (DC) } \\
\text { system }\end{array}$ & Liability of: & $\begin{array}{l}\text { Returns } \\
\text { financed } \\
\text { through: }\end{array}$ & $\begin{array}{l}\text { Rate of } \\
\text { return }\end{array}$ & $\begin{array}{l}\text { Political risk: } \\
\text { manipulation }\end{array}$ & $\begin{array}{l}\text { Economic risk: } \\
\text { What happens if } \mathrm{r}>\mathrm{g}\end{array}$ \\
\hline NDC & Government & $\begin{array}{l}\text { Real } \\
\text { economy }\end{array}$ & $\mathrm{r} \equiv \mathrm{g}$ & $\begin{array}{l}\text { Moderate or } \\
\text { even small }\end{array}$ & Not possible \\
\hline FDC $\mathrm{GD}$ & Government & $\begin{array}{l}\text { Financial } \\
\text { markets }\end{array}$ & $\mathrm{r}=\mathrm{r}_{\mathrm{GD}}$ & Small & $\begin{array}{l}\mathrm{GDP}^{\mathrm{R}} / \mathrm{GDP} \text { increases } \\
\text { due to higher taxes }\end{array}$ \\
\hline FDC & $\begin{array}{l}\text { Private } \\
\text { sector }\end{array}$ & $\begin{array}{l}\text { Financial } \\
\text { markets }\end{array}$ & $\mathrm{r}=\mathrm{r}_{\mathrm{PE}}$ & Very small & $\begin{array}{l}\text { GDP } / \mathrm{GDP} \text { increases } \\
\text { due to higher asset } \\
\text { prices }\end{array}$ \\
\hline \hline
\end{tabular}

In the table: $\mathrm{g}$ - GDP growth rate; $\mathrm{r}$ - pension system rate of return.

In order to avoid substantial leakage from the pension system, as well as to avoid failing to achieve the social goal of the system, each account type should be annuitised at the moment of retirement. Without annuitisation, and if participants overestimate their longevity, then pension obligations will be inherited and finance non-pension goals. There is no sense in mandating people to participate in the pension system and afterwards let their obligations finance goals that can be better financed outside the mandatory system. Instead it is much better to reduce contributions in advance. On the other hand, if participants underestimate their longevity then a social problem will arise. It will have to be solved by increasing taxes. Both cases will generate negative externalities.

All three types of individual accounts provide the system with stability (Equation 2) at the macro level, and safety, transparency and fairness at the micro level (Equation 3).

$$
P V_{t}(C)=P V_{t}(B)
$$

\footnotetext{
${ }^{14}$ More on different types of individual accounts can be read in Góra and Palmer (2002).
} 


$$
\mathrm{C}, \mathrm{B}-\text { contribution and benefit sum. }
$$

The present value of the sum of benefits paid out from the system equals the present value of the sum of contributions paid into the system. Both sums can fluctuate. In order to smooth fluctuations technical reserves need to be created.

$$
\begin{aligned}
& P V_{t}\left(c_{i}\right)=E\left[P V_{t}\left(b_{i}\right)\right] \\
& \mathrm{c}_{\mathrm{i}}, \mathrm{b}_{\mathrm{i}}-\text { individual contributions and benefits. }
\end{aligned}
$$

Expected value of individual benefits (annuities) received from the system equals the present value of individual contributions paid to the system.

In addition to the features mentioned above, each type of individual account causes specific effects.

$>$ The NDC type of pension system is the easiest to implement (no costs, no fiscal problems). After maturation NDC divides GDP between generations in a stable proportion. NDC is neutral by definition.

$>\mathrm{FDC}_{\mathrm{GD}}$ is more difficult for implementation (no costs, some fiscal problems). If for any reason government debt is overvalued by the financial markets $(r>g)$ then the pension system may contribute to an increase in taxation. A benefit is that this type of account contributes to the development of the financial markets.

$>\mathrm{FDC}_{\mathrm{PE}}$ is the most difficult for implementation (some (minor) costs, fiscal problems). $\mathrm{FDC}_{\mathrm{PE}}$ generates positive externalities for growth, such as increased investment. In the case of this type of account it is also possible that $\mathrm{r}>\mathrm{g}$. However, this problem can be solved by the reduction of the contribution rate, which will offset the increase of the scale of allocation of GDP to the retired generation.

The three types of individual accounts differ from each other in many ways. The differences, however, have very little, if anything, to do with the traditional opposition of pay-as-you-go and funding, as none of the account types can be attributed to payas-you-go systems.

One can argue that both versions of FDC are superior to NDC, as they provide participants with better protection of their rights against political manipulation. This could be true, but only to some extent. Actually, all three types of individual accounts 
protect pension rights much better than can be achieved without such accounts. FDC can also be affected by politics through the manipulation of taxation.

However, what matters much more is the fact that pension systems pay more than they can afford to. Even if FDC really protected the pension rights better than NDC this does not matter much, as it is rewarding production factors that need to be protected. Pension systems attempt to increase $\mathrm{GDP}^{\mathrm{R}}$ at the expense of the working population. The real risk pension systems are exposed at is inflating pension rights rather than violating them.

\section{$\underline{\text { Pension system participation: Individualisation versus privatisation }}$}

Individualisation of pension system participation plays an important role in the pension system. Individualisation reduces the perception that pension contributions are taxes; hence, this reduces tax distortions and contributes to stronger growth. However, individualisation should not be confused with privatisation of the system. Privatisation can be applied to system management, contracts, claims, and/or asset management. ${ }^{15}$ Each of these activity areas could be in either the public or the private domain. Individualisation creates a full and transparent link between contributions and returns on them on one hand, and benefits on the other.

The rationale behind mandating participation in the universal pension system is to achieve a public goal. This is the only element of the system that cannot be privatised. The system remains public, even if it is privately managed.

\section{Pensions: Summary of the proposed approach}

Typically pension economics, as well as popular discussions, use the following opposing concepts as a central basis for thinking on pensions:

Pay-as-you-go versus funding;

Public versus private;

Monopillar versus multipillar.

\footnotetext{
${ }^{15}$ See Góra and Palmer (2002).
} 
This paper presents an alternative approach. This alternative approach can be summarised in the following four pairs of opposing concepts:

Universal (mandatory covering the entire population) versus partial (voluntary participation of a group of people);

Individualised (individual accounts) versus anonymous (no accounts) participation;

Task specific/segmented (OA separated from NOA) versus multitask (OA and NOA mixed within one scheme) organisation of social security;

Financial (generating the rate of return through financial markets) versus nonfinancial (generating the rate of return through real economy growth).

The efficient pension system is designed in a way that makes it endogenous, which means it adjusts automatically without intervening from outside. The system needs only one decision, namely the initial choice of the contribution rate.

The way of thinking on pensions based on the above set of comparisons can be useful for better describing and analysing the pension system. This approach can also let the discussion on pensions go beyond the hopeless controversy of those who promote private funded pension funds and those who promote what is called the pay-as-you-go system.

As such policy makers in the European Union and elsewhere could benefit using the proposed methodology when looking at reforming their pension systems.

\section{Key features of the new Polish pension system}

The new Polish pension system design is a good example of applying the above described way of thinking in practice. The system named "Security through Diversity" started on 1 January 1999. It entirely replaced previous regulations on oldage pensions for majority of working population. Designing the new system from scratch provided the unique opportunity to avoid complicating the system. Instead, the new system design is simple and transparent. The main goal was to design a system that can be neutral or at least close to neutrality for economic growth irrespective of population ageing. 
The design of the new system does not copy any other pension system existing elsewhere. Strong similarity can be found only to the new Swedish pension system based on similar principles and started on the same day. ${ }^{16}$ At the same time, within this general framework the new Polish system uses a number of technical concepts developed in other countries. This brief presentation of the new Polish pension system focuses on the general economic design of the system, while leaving aside most technical details.

The following bullets help in grasping the essence of the concept of the new Polish system design.

Focusing on the universal part of the pension system;

Separation of the old-age part of social security (OA) from the non-old-age parts of social security (NOA); and segmenting the flows of revenue;

Termination of the OA part of the previous system;

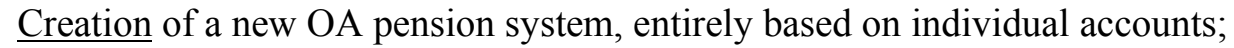

Accrual accounting within the OA system;

Splitting each person's OA contributions between two accounts (first account NDC, second account - FDC);

Annuitisation of account values (NDC as well as FDC) at the moment of retirement;

Minimum pension supplement on the top of both annuities if their sum is below certain level (financed out of the state budget).

NDC - individual accounts based on government quasi-bonds (idea similar to Buchanan bonds) not traded in financial markets, bringing a rate of return that equals the wage sum growth (GDP growth in long run). ${ }^{17}$

FDC - individual accounts based on instruments traded in financial markets. ${ }^{18}$

\footnotetext{
${ }^{16}$ For comprehensive information on the new Swedish pension system see Palmer (2002).

${ }^{17}$ At the moment, there is a kind of tax imposed on NDC returns. Its role is to reduce GDP ${ }^{\mathrm{R}}$ sooner.

${ }^{18}$ There is no tax on returns at the moment.
} 
It should be strongly stressed that both accounts are annuitised at the same moment and play exactly the same role within social security. In particular there is no such element of the system as a "basic state pension". Social redistribution exists but it has been moved out from the pension system. The sole role of the pension system is providing working generation with an efficient method of income allocation over their life cycle.

The contribution rate for the entire social security system has not changed. However workers' salaries were "grossed up" in order to introduce to them the idea that they pay part of the contribution and to build their awareness of the overall cost of the pension system. As such, since 1 January 1999 both workers and employers share the cost of contributions without any real change in the size of the total contributions. The whole operation affected percentages but not real flows of money. Thus the new system is based on the same contribution inflow as the previous system.

The contribution due for a worker is divided into four pieces in order to define each part of the system well. The main element of the change is splitting the contribution into the old age (OA) and the other three non-old-age (NOA) (see Table 2).

Table 2. Mandatory contributions in Poland before and after implementation of the new pension system

\begin{tabular}{|c|c|c|c|c|}
\hline & Total & $\begin{array}{c}\text { NDC individual } \\
\text { account }\end{array}$ & $\begin{array}{l}\text { FDC individual } \\
\text { account }\end{array}$ & $\begin{array}{l}\text { Other elements } \\
\text { of the system }\end{array}$ \\
\hline \multicolumn{5}{|c|}{ before 1-Jan-1999 } \\
\hline $\begin{array}{l}\text { Mandatory } \\
\text { contribution }\end{array}$ & $36.59^{\mathrm{a}}$ & -- & -- & 36.59 \\
\hline \multicolumn{5}{|c|}{ since 1-Jan-1999 } \\
\hline $\begin{array}{l}\text { Mandatory old-age } \\
(\mathrm{OA}) \text { contribution }\end{array}$ & 19.52 & 12.22 & 7.3 & -- \\
\hline $\begin{array}{c}\text { Other mandatory } \\
\text { social welfare (NOA) } \\
\text { contributions }\end{array}$ & 17.07 & -- & -- & 17.07 \\
\hline
\end{tabular}

\footnotetext{
${ }^{\mathrm{a}}$ Equivalent of 45 percent (after grossing-up of labour income).
} 
Retirement age does not play any active role in the balancing revenue and expenditure sides of the new system. Retirement age is still important from the social policy and labour supply point of view. For these reasons, in the new system the minimum retirement age is set at 60 for women and 65 for men. ${ }^{19}$ However, unlike a traditional pension system, this new system can be run at any retirement age. ${ }^{20}$

From the individual perspective, the new system is a method of life cycle income allocation.

$>$ Contributions based on a fixed percent of individual earnings create account values.

Account balances from the close of the preceding period earn a rate of return based on the growth of the sum of paid contributions.

Accumulated account values are annuitised at the time of retirement

Annuities are calculated on the basis of accumulated capital and life expectancy at the age of retirement.

From macroeconomic perspective the system is a method of sharing GDP between generations. The key feature of this system is stabilisation of the share being transferred to the entire retired generation $\left(\mathrm{GDP}^{\mathrm{R}}\right)$. Technical (demographic) reserves are created in the system in order to smooth fluctuations that inevitably influence its revenue and expenditure side.

Pillar terminology is often used in the area of pensions and with some confusion as to definitions and depending upon who is doing the classification. ${ }^{21}$ To some extent it is used also in Poland, especially for public communications. However, it fits the Polish case only partially. If we use this terminology we should say there is no first pillar in the system. At the same time the second pillar consists of two types of individual accounts (two accounts per participant, one $\mathrm{NDC}$, the other $\mathrm{FDC}_{\mathrm{GD}} / \mathrm{FDC}_{\mathrm{PE}}$ ) that have

\footnotetext{
${ }^{19}$ Initial reform project set retirement age at 62 for both genders. For political reasons this was not accepted. Hopefully this will be possible in the future but up to now no decision has been taken.

${ }^{20}$ It should be remembered that people who retire now are those who are still covered by the old system - those whom the new system covered were in the beginning or middle of their working life and so will not retire for a number of years yet. So the age of their retirement matters.

${ }^{21}$ For instance, the name "second pillar" can be attributed to a part of the universal system (World Bank terminology) or to occupational (partial) schemes (terminology used in many countries).
} 
the same objective (income allocation) but use different ways of generating the rate of return (through real economy or through financial markets). Table 3 presents a comparison of key features of the three-pillar approach and the Polish approach.

Table 3. Alternative approaches to pension reform

\begin{tabular}{|c|c|}
\hline Typical "three pillar" reform & Security through Diversity \\
\hline $\begin{array}{l}\text { Rationalised old system (redistribution; } \\
\text { anonymous participation) „first pillar” } \\
\text { New part of the system based on } \\
\text { financial individual accounts run by } \\
\text { private asset managers „,second pillar” } \\
>\text { Contribution split between the old and } \\
\text { the new system } \\
>\text { Promotion of various forms of } \\
\text { additional savings „third pillar” }\end{array}$ & $\begin{array}{l}>\text { Splitting social security into OA and } \\
\text { NOA } \\
>\text { Termination of the OA part of the old } \\
\text { system } \\
>\text { Creation of entirely new OA part of the } \\
\text { system (individual accounts of two } \\
\text { types; annuitisation on retirement; no } \\
\text { redistribution) } \\
>\text { Contribution split between two } \\
\text { accounts } \\
>\text { First account - non- financial; rate of } \\
\text { return determined by GDP growth; } \\
\text { publicly run (possible privatisation) } \\
>\text { Second account - financial; rate of } \\
\text { return determined in financial markets; } \\
\text { privately run } \\
>\text { Annuitisation of account values (both } \\
\text { accounts) } \\
>\text { Promotion of various forms of } \\
\text { additional savings }\end{array}$ \\
\hline
\end{tabular}

Starting from 1 January 1999 the entirely new system replaced the old one for all people born after 31 December 1948. Participation in the new system was not subject to individual choice. The new system automatically covered the entire group of people born after that date. There was no switching. ${ }^{22}$ However, a group of participants took decisions on choosing one of two versions of the new system.

\footnotetext{
${ }^{22}$ Offering people the opportunity to take decisions is usually well received. However, the idea of universal system means not only universal coverage but also universal rules. Choice is an illusion in a mandatory system, which can impose problems. Choice is appropriate for voluntary partial programmes.
} 
Decisions were taken in the period until 31 December 1999. Table 4 provides summary of the procedure. ${ }^{23}$

Table 4. Introduction of the new system (age groups)

\begin{tabular}{|c|c|c|}
\hline \multicolumn{2}{|c|}{ New system (people born after 31 Dec. 1948) } & \multirow{2}{*}{$\begin{array}{l}\text { Old system (people born } \\
\text { before 1 Jan. 1949) }\end{array}$} \\
\hline $\begin{array}{c}\text { People born } \\
\text { after } 31 \text { Dec. } 1968\end{array}$ & $\begin{array}{c}\text { People born } \\
\text { before } 1 \text { Jan. } 1969\end{array}$ & \\
\hline $\begin{array}{c}\text { Automatically covered by } \\
\text { the new system; OA } \\
\text { contribution automatically } \\
\text { split between two accounts } \\
\text { [NDC+FDC] }\end{array}$ & $\begin{array}{l}\text { Automatically covered by } \\
\text { the new system; OA } \\
\text { contribution either split } \\
\text { between two accounts or } \\
\text { paid into one account } \\
\text { [(NDC+FDC) or NDC] }\end{array}$ & $\begin{array}{l}\text { Stay in the old system (no } \\
\text { possibility to participate in } \\
\text { the new one); } \\
\text { no accounts }\end{array}$ \\
\hline
\end{tabular}

The new system covered people who had been previously covered by the old system. To be just, already acquired pension rights in the old system had to be recognized in the new system. A special procedure transformed them into account values. Everybody who had started participation before 1 January 1999 received on their NDC account an amount called "initial capital", reflecting present value of the rights acquired under the old system.

This procedure can be interpreted as retirement of the entire population born after 31 December 1948, in that they retired according to the old rules (but at an earlier date). Their hypothetical benefits were recalculated into amounts that would have been needed after reaching retirement age for generating a flow of these benefits. After sending all participants to retirement, the old system was terminated.

It should be stressed that the way of implementation of the new system was rather radical, in that it put a complete end to the old system for the vast majority of the population. This was possible due to the way in which the system is designed.

\footnotetext{
${ }^{23}$ There were two major exceptions from the procedure presented in Table 4. Agricultural workers kept being covered by a special pension scheme. The so-called uniform services (army, police) were covered by the new universal system but that concerned only those who started their servicing after 31 December 1998, while the rest of this group stayed in their special pension scheme.
} 
Attempts to introduce minor modifications in pension systems lead to much stronger social unrest than reforms changing the rules behind the system. In Poland, there was no significant public critique of the way of implementation of the new system and in many ways the reform was enthusiastically received.

Implementation of the new system means ex ante adjustment of the flow of its future expenditure. This produces very strong macroeconomic effects. Almost $€ 1 / 2$ trillion (in 2000 prices) is the value of debt that will not be created until 2050 due to implementation of the new OA pension system. ${ }^{24}$ Table 5 provides comparative projections for OECD countries on demographic dependency ratio, pension expenditure and primary surpluses needed to keep debts at their 2000 levels. In comparison to projections made for other countries the Polish case looks really very strong. The lack of a large part of the pension debt - and hence no need to finance its servicing - will give a great deal of freedom to both the public and private sector to achieve various goals contributing to the country's development.

Two conclusions on the Polish case can be drawn from the projections provided in Table 5:

> The demographic situation (measured by the dependency ratio) will change from relatively good now to one of the worst in the OECD area in 2050.

At the same time - due to implementation of the new system - OA pension expenditure will substantially drop from one of the highest levels now to one of the lowest in the OECD area in 2050.

Implementation of the new pension system is a complicated task. The structure of the system needs to be serviced by various institutions. Management of the pension system is an important issue for consideration when designing the system. However, management should not be confused with the system itself. This paper does not focus on these issues, but Box 1 summarises the most key Polish institutions in the reform and their responsibilities.

\footnotetext{
${ }^{24}$ For details on projections see Chłoń-Domińczak (2002).
} 
Table 5. Projected effects as compared to other European countries

\begin{tabular}{|c|c|c|c|c|c|c|c|c|}
\hline & \multicolumn{3}{|c|}{ Dependency ratio } & \multicolumn{3}{|c|}{ Pension expenditure (\%GDP) } & \multicolumn{2}{|c|}{$\begin{array}{c}\text { Primary surplus required } \\
(\% \mathrm{GDP})\end{array}$} \\
\hline & 2000 & 2050 & Change & 2000 & 2050 & Change & Debt constant & Debt reduced \\
\hline Australia & 20.4 & 47.0 & 26.6 & 3.0 & 4.5 & 1.5 & ... & ... \\
\hline Austria & 25.2 & 58.2 & 33.0 & 9.5 & 11.8 & 2.3 & .. & .. \\
\hline Belgium & 28.1 & 49.5 & 21.4 & 8.8 & 12.1 & 3.3 & 4.2 & 5.3 \\
\hline Canada & 20.4 & 45.9 & 25.5 & 5.1 & 11.0 & 5.9 & 3.7 & 4.5 \\
\hline Czech Republic & 21.9 & 57.5 & 35.6 & 7.8 & 14.6 & 6.8 & 1.6 & 1.8 \\
\hline Denmark & 24.2 & 40.3 & 16.1 & 6.1 & 8.8 & 2.7 & 3.7 & 4.0 \\
\hline Finland & 25.9 & 50.6 & 24.7 & 8.1 & 12.9 & 4.8 & 2.5 & 2.1 \\
\hline France & 27.2 & 50.8 & 23.6 & 12.1 & 15.8 & 3.7 & 5.9 & 6.6 \\
\hline Germany & 26.6 & 53.2 & 26.6 & 11.8 & 16.9 & 5.1 & 4.3 & 4.7 \\
\hline Hungary & 23.7 & 47.2 & 23.5 & 6.0 & 7.2 & 1.2 & .. & .. \\
\hline Island & 20.3 & 44.0 & 23.7 &.. &.. &.. &.. &.. \\
\hline Ireland & 19.7 & 45.7 & 26.0 & .. &.. & .. &.. &.. \\
\hline Italy & 28.8 & 66.8 & 38.0 & 14.2 & 13.9 & -0.3 & 4.9 & 5.9 \\
\hline Japan & 27.7 & 64.6 & 36.9 & 7.9 & 8.5 & 0.6 & 3.6 & 4.1 \\
\hline Korea & 11.3 & 45.4 & 34.1 & 2.1 & 10.1 & 8.0 & 3.9 & 3.5 \\
\hline Netherlands & 21.9 & 44.9 & 23.0 & 5.2 & 10.0 & 4.8 & 6.1 & 6.6 \\
\hline New Zealand & 20.4 & 48.3 & 27.9 & 4.8 & 10.6 & 5.8 & 2.9 & 2.9 \\
\hline Norway & 25.6 & 41.2 & 15.6 & 4.9 & 12.9 & 8.0 & 4.6 & 4.0 \\
\hline Poland & 20.4 & 55.2 & 34.8 & 10.8 & 8.3 & -2.5 & -1.0 & -1.0 \\
\hline Portugal & 26.7 & 50.9 & 24.2 & 8.0 & 12.5 & 4.5 & 3.4 & 3.4 \\
\hline Spain & 27.1 & 65.7 & 38.6 & 9.4 & 17.4 & 8.0 & 4.8 & 5.2 \\
\hline Sweden & 29.4 & 46.3 & 16.9 & 9.2 & 10.8 & 1.6 & 1.0 & 1.1 \\
\hline Switzerland & 25.1 & 45.3 & 20.2 &.. &.. &.. &.. & .. \\
\hline UK & 26.6 & 45.3 & 18.7 & 4.3 & 3.6 & -0.7 & 0.8 & 1.2 \\
\hline USA & 21.7 & 37.9 & 16.2 & 4.4 & 6.2 & 1.8 & 2.7 & 3.2 \\
\hline OECD (avg.) & 23.8 & 49.9 & 26.1 & 7.4 & 10.6 & 3.2 & .. & .. \\
\hline
\end{tabular}

Source: OECD. See Dang et al. (2001).

Notice: If only pension expenditure is taken into account then the required surplus needed in the case of Poland is even more favourable (-2.8\% GDP).

It should be added that managing the majority of tasks can be privatised. This is important and will likely improve the efficiency of managing the tasks. However, this is a subject of public choice and is not crucial for the pension system itself.

Although management issues are not discussed in this paper, it needs to be mentioned that the day-to-day operations of the new Polish pension system has had some difficulties. There are a number of problems concerning processing of information. Such information management is essential for the individualised system. The system really only needs four pieces of information on each participant, namely: name, amount paid, date of payment and wage. The wage information is needed only for control purposes. In practice, however, much more information is being collected, and 
this has led to problems. Nevertheless, these day-to-day operational issues should not be confused with the overall soundness of the policy design.

\begin{tabular}{|ll|}
\hline Box 1. Tasks and managing institutions & \\
Registration and other initial procedures & ZUS \\
Collection of contributions & ZUS (can be privatised) \\
Transfer of contributions to OA individual & \\
accounts and NOA parts of social security & ZUS (can be privatised) \\
Running NDC accounts & ZUS (can be privatised) \\
Running FDC accounts & Pension Societies (asset \\
& managers) (private) \\
Providing NDC annuities & ZUS (can be privatised) \\
Providing FDC annuities & Annuity companies (private) \\
\hline
\end{tabular}

ZUS=social security institute

The Polish pension reform has yet another feature that is worth mentioning. The new system financing is based on accrual accounting. ZUS neither used segmentation nor accrual accounting at the start of the new system, and so this tied with the IT system problem created the backlog. Information technology implementation has been the curse of more than one new public policy initiative. The IT system has now got the segmentation and accrual accounting working almost correctly. Implementation of the accrual accounting is in line with a general movement from cash accounting (traditional in social security, as well as other government activities) to accrual accounting, which better ties together income and expenses and allows for easier tracking of information and money.

\footnotetext{
${ }^{25}$ This element of the institutional structure serving the pension system still needs more legislation.
} 
Key factors behind the success of the pension reform in Poland

Pension reform is a difficult challenge. Success is not guaranteed. Actual experience indicates that failure is rather very likely. Recent evidence from many European countries illustrates this very clearly. However, Poland's case is a success. How was this possible? Here are key factors that helped:

$>$ The new system was designed by economists, who were able to focus on inputs, outputs and means of the system (rather than by traditional social security experts, who tend to focus mostly on outputs of the system);

The reform team was decoupled from politics, and understood to be made up of non-political specialists;

The new system was designed without pre-set political guidelines;

The reform team enjoyed political protection from various political powers, under various governments;

$>$ The reform project was presented to the public without strong political affiliation;

$>$ The reform team was not linked to institutions involved in running the old pension system;

$>$ Pre-reform rationalization of the system was not presented to the public as a reform;

$>$ The new system was presented to the public as a new opportunity (actuarial link of contributions and benefits), not as cutting down old system promises;

Strong marketing of the new system (media, social partners);

$>$ The new system was designed and implemented before the real pension crisis started;

The reform did not affect pensioners and workers already close to retirement;

The reform did not increase labour cost;

The old system was terminated but pension rights acquired under its rule were not lost or reduced.

Discussion of these other factors would be the subject of another paper. 


\section{Final remarks}

Providing people with social security - including financing consumption of the retired generation out of the product of the working generation - is very high on the list of social priorities in most countries. It is especially important in European societies. However, the inefficiency of traditional pension systems put achieving this goal at risk. Social and populist rhetoric suggests to the public that changes within the pension system are dangerous for social goals. In reality, for most countries in the world, it is just the opposite. The longer the traditional pension systems are held up, the more socially damaging effects will be created.

Poland belongs to a non-numerous group of countries that are prepared for one of the most difficult challenges of our time, namely the ageing of the population. The new pension system will not only stop the increase of costs of the pension system but will also allow for their reduction. This will leave more resources available for development, which, in turn, will contribute to stronger growth and the increase of living standards of both the working and the retired generation.

The example of the new Polish pension system, as well as the Swedish one, is interesting for yet another reason. This type of system contributes to labour mobility, which is particularly needed in Europe. Free movement of labour cannot be achieved if moving from one country to another affects expected retirement income. As such, aiming at pension system neutrality will be more and more important for European integration. 


\section{References}

Barr, Nicholas, 2002, „Reforming Pensions: Myths, Truths, and Policy Choices”, International Social Security Review, Vol. 55, No. 2, pp.3-36.

Chłoń-Domińczak, Agnieszka, 2002, „The Polish Pension Reform of 1999”, in Fultz, Elaine (ed.) Pension Reform in Central and Eastern Europe, Volume 1, Restructuring with Privatization: Case Studies of hungary and Poland, Budapest.

Chlon, Agnieszka, Marek Góra, Michal Rutkowski, 1999, "Shaping Pension Reform in Poland: Security through Diversity", SP Discussion Paper No. 9923, Pension Reform Primer, World Bank, Washington, D.C.

Dang, Thai Than, Pablo Antolin and Howard Oxley, 2001, "Fiscal Implications of Ageing: Projections of Age-Related Spending", Economics Department Working Paper No. 305, OECD, Paris.

Góra, Marek, 2001, "Polish Approach to Pension Reform", Private Pension Systems, No. 3, pp.227-246.

Góra, Marek, 2003a, The Pension System, Polskie Wydawnictwo Ekonomiczne (PWE) [in Polish].

Góra, Marek, 2003b, “The quest for modern pension system”, in G. Tumpel-Gugerell and P. Mooslechner (eds.), Structural Challenges for Europe, Edward Elgar (forthcoming).

Góra, Marek and Edward Palmer, 2002, "Shifting Perspectives in Pensions", CASE (www.case.com.pl).

Góra, Marek and Michal Rutkowski, 1998, "The Quest for Pension Reform: Poland's Security through Diversity", SP Discussion Paper No. 9815, Pension Reform Primer, World Bank, Washington, D.C.

Holzmann, Robert, Mitchel Orenstein and Michal Rutkowski, eds, 2003, Pension Reform in Europe: Process and Progress, The World Bank, Washington, D.C.

Palmer, Edward, 2002, "Swedish Pension Reform - How Did It Evolve and What Does It Mean for the Future?" in Feldstein, M and H. Siebert (eds.) Coping with the Pension Crisis: Where Does Europe Stand? Chicago: University of Chicago Press.

van de Kaa, D.J. 1996, "Anchored narratives: the story and findings of half a century of research into the determinants of fertility", Population Studies 50, No. 3, pp. 389-432. 


\section{DAVIDSON INSTITUTE WORKING PAPER SERIES - Most Recent Papers}

The entire Working Paper Series may be downloaded free of charge at: www.wdi.bus.umich.edu

CURRENT AS OF 6/16/03

\begin{tabular}{|c|c|c|}
\hline Publication & Authors & Date \\
\hline $\begin{array}{l}\text { No. 578: Shadow Economy, Rent-Seeking Activities and the Perils of } \\
\text { Reinforcement of the Rule of Law }\end{array}$ & Ekaterina Vostroknutova & June 2003 \\
\hline $\begin{array}{l}\text { No. 577: No Pain, No Gain: Market Reform, Unemployment, and } \\
\text { Politics in Bulgaria }\end{array}$ & Neven Valev & June 2003 \\
\hline $\begin{array}{l}\text { No. 576: Power Analysis of the Nice Treaty On the Future of European } \\
\text { Integration }\end{array}$ & Yener Kandogan & June 2003 \\
\hline $\begin{array}{l}\text { No. 575: Democracy's Spread: Elections and Sovereign Debt in } \\
\text { Developing Countries }\end{array}$ & $\begin{array}{l}\text { Steven A. Block, Burkhard N. } \\
\text { Schrage, and Paul M. Vaaler }\end{array}$ & June 2003 \\
\hline $\begin{array}{l}\text { No. 574: Reintroducing Intergenerational Equilibrium: Key Concepts } \\
\text { Behind the New Polish Pension System }\end{array}$ & Marek Góra & June 2003 \\
\hline $\begin{array}{l}\text { No. 573: Why Does FDI Go Where It Goes? New Evidence From the } \\
\text { Transition Economies }\end{array}$ & $\begin{array}{l}\text { Yuko Kinoshita and Nauro F. } \\
\text { Campos }\end{array}$ & June 2003 \\
\hline $\begin{array}{l}\text { No. 572: Private Savings in Transition Economies: Are There Terms of } \\
\text { Trade Shocks? }\end{array}$ & Abdur R. Chowdhury & May 2003 \\
\hline $\begin{array}{l}\text { No. 571: On the long-run determinants of real exchange rates for } \\
\text { developing countries: Evidence from Africa, Latin America and Asia }\end{array}$ & Imed Drine and Christophe Rault & May 2003 \\
\hline $\begin{array}{l}\text { No. 570: A re-examination of the Purchasing Power Parity using non- } \\
\text { stationary dynamic panel methods: a comparative approach for } \\
\text { developing and developed countries }\end{array}$ & Imed Drine and Christophe Rault & May 2003 \\
\hline $\begin{array}{l}\text { No. 569: How Important is Ownership in a Market with Level Playing } \\
\text { Field? The Indian Banking Sector Revisited }\end{array}$ & $\begin{array}{l}\text { Sumon Kumar Bhaumik and } \\
\text { Ralitza Dimova } \\
\end{array}$ & May 2003 \\
\hline $\begin{array}{l}\text { No. 568: On Types of Trade, Adjustment of Labor and Welfare Gains } \\
\text { During Asymmetric Liberalizations }\end{array}$ & Yener Kandogan & May 2003 \\
\hline $\begin{array}{l}\text { No. 567: Technological Progress Through Trade Liberalization in } \\
\text { Transition Countries }\end{array}$ & Yener Kandogan & May 2003 \\
\hline $\begin{array}{l}\text { No. 566: Intra-industry Trade of Transition Countries: Trends and } \\
\text { Determinants }\end{array}$ & Yener Kandogan & May 2003 \\
\hline $\begin{array}{l}\text { No. 565: Local Protectionism and Regional Specialization: Evidence } \\
\text { from China's Industries }\end{array}$ & $\begin{array}{l}\text { Chong-En Bai, Yingjuan Du, } \\
\text { Zhigang Tao, Sarah Y. Tong } \\
\end{array}$ & May 2003 \\
\hline No. 564: Corporate Governance and Market Valuation in China & $\begin{array}{l}\text { Chong-En Bai, Qiao Liu, Joe Lu, } \\
\text { Frank M. Song, and Junxi Zhang }\end{array}$ & May 2003 \\
\hline $\begin{array}{l}\text { No. 563: Revenue Sharing and Control Rights in Team Production: } \\
\text { Theories and Evidence From Joint Ventures }\end{array}$ & $\begin{array}{l}\text { Chong-En Bai, Zhigang Tao, and } \\
\text { Changqi Wu }\end{array}$ & May 2003 \\
\hline $\begin{array}{l}\text { No. 562: Financial Dependence, Stock Market Liberalizations and } \\
\text { Growth }\end{array}$ & Nandini Gupta and Kathy Yuan & May 2003 \\
\hline $\begin{array}{l}\text { No. 561: Growth and Regional Inequality in China During the Reform } \\
\text { Era }\end{array}$ & Derek Jones, Cheng Li and Owen & May 2003 \\
\hline $\begin{array}{l}\text { No. 560: Choice of Ownership Structure and Firm Performance: } \\
\text { Evidence from Estonia }\end{array}$ & $\begin{array}{l}\text { Derek Jones, Panu Kalmi, Niels } \\
\text { Mygind }\end{array}$ & May 2003 \\
\hline No. 559: Explaining Postcommunist Economic Performance & Lawrence P. King & May 2003 \\
\hline $\begin{array}{l}\text { No. 558: Tax Structure and the FDI: The Deterrent Effects of } \\
\text { Complexity and Uncertainty }\end{array}$ & $\begin{array}{l}\text { Kelly Edmiston, Shannon Mudd } \\
\text { and Neven Valev }\end{array}$ & Apr. 2003 \\
\hline No. 557: Provincial Protectionism & Konstantin Sonin & Apr. 2003 \\
\hline $\begin{array}{l}\text { No. 556: Nominal and Real Convergence in Estonia: The Balassa- } \\
\text { Samuelson (dis)connection }\end{array}$ & Balázs Égert & Apr. 2003 \\
\hline $\begin{array}{l}\text { No. 555: Banks-Firms Nexus under the Currency Board: Empirical } \\
\text { Evidence from Bulgaria }\end{array}$ & $\begin{array}{l}\text { Nikolay Nenovsky, Evgeni Peev } \\
\text { and Todor Yalamov }\end{array}$ & Apr. 2003 \\
\hline $\begin{array}{l}\text { No. 554: To Steal or Not to Steal: Firm Attributes, Legal Environment, } \\
\text { and Valuation }\end{array}$ & Art Durnev and E. Han Kim & Apr. 2003 \\
\hline No. 553: Corporate Stability and Economic Growth & $\begin{array}{l}\text { Kathy S. He, Randall Morck and } \\
\text { Bernard Yeung }\end{array}$ & Apr. 2003 \\
\hline
\end{tabular}

